\title{
Випадок прогресивної деменції на тлі пізнього нейросифілісу
}

\author{
Г.М. Бондаренко, І.М. Нікітенко, О.А. Безрученко, В.В. Кутова, Т.В. Губенко \\ ДУ «Інститут дерматології та венерології НАМН України»
}

\begin{abstract}
Резюме
Мета. Запобігання діагностичним помилкам, пов'язаним із рідкістю виявлення сифілісу у хворих неврологічних стаціонарів.

Результати. Наведено клінічний випадок із практики лікарів-дерматовенерологів.

Висновки. Для своєчасного виявлення нейросифілісу необхідно проводити лікворологічне обстеження всіх пацієнтів неврологічного стаціонару, що мають позитивний результат нетрепонемних і трепонемних тестів із сироваткою крові.

Ключові слова: нейросифіліс, Treponema pallidum, деменція, діагностика нейросифілісу.

DOI: 10.33743/2308-1066-2021-2-31-34
\end{abstract}

\section{Вступ}

Під нейросифілісом (НС) розуміють ураження нервової системи з можливими функціональними i/або органічними іï ушкодженнями, спричинені блідою трепонемою (Treponema pallidum), які супроводжуються специфічними змінами в лікворі. Існуючі нині класифікації НС враховують давність сифілітичної інфекції і провідні клінічні зміни [3].

Частота ураження нервової системи при сифілісі варіює від 22,6 до 30\% і може сягати 90\% [10]. Такі відмінності пояснюються використанням різних критеріїв діагностики НС, неоднаковою повнотою обстеження хворих (зокрема серологічного і лікворологічного), а також клінічним патоморфозом [12]. Важливе значення має і тверда упевненість клініцистів у майже повній ліквідації НС [8].

У публікаціях Marra С. вказується, що за відсутності лікування раннього сифілісу НС виникає в 30\% випадків [13]. У розвитку ураження нервової системи разом з інфекційним агентом велике значення мають такі чинники, як пізня діагностика сифілісу, зниження імунореактивності організму та недостатнє лікування сифілісу в анамнезі [11]. Проте є дані [7], що в 10\% хворих НС розвивається і після повноцінного лікування сифілісу.

Обтяжуючими факторами розвитку НС є психічні і фізичні травми, різного роду інтоксикації (алкоголізм, наркоманія), а також атеросклероз з ураженням мозкових судин, психоемоційні перевантаження, супутні важкі соматичні захворювання [2].

Динаміка патологічного процесу при НС дає змогу розділити його на дві групи: ранній мезенхімальний і пізній паренхіматозний. Обидві групи є крайніми ланками єдиного імунопатологічного процесу [5].

Ранні (мезенхімальні) зміни при НС характеризуються першочерговим ураженням судин і м'яких мозкових оболонок головного і спинного мозку з переважанням ексудативно-запальних процесів. Як правило, вони розвиваються не пізніше 5 років після зараження.
Пізні (паренхіматозні) зміни характеризуються ураженням мозкової паренхіми з переважанням дегенеративно-дистрофічних процесів. Як правило, вони розвиваються не раніше ніж через 5-8 років. Для них характерні повільно наростаючі дегенеративні зміни нервових клітин і волокон. У патологічний процес зазвичай залучаються і мезенхімальні елементи [4].

Розподіл НС на мезенхімальний і паренхіматозний не визначає повністю усіх сторін морфологічної картини. Розмежувати ці форми за хронологічним принципом також не є можливим. Крім того, усі прояви раннього і пізнього НС являють собою різні поєднання симптомів мезенхімального і паренхіматозного ушкоджень [9].

Клінічна картина НС останніми роками дещо змінилася. Спостерігається почастішання випадків раннього НС з переважанням менінговаскулярних форм. Клінічна симптоматика пізнього НС має неспецифічний характер дифузного багатовогнищевого ураження ЦНС [9]. Найбільші відхилення в неврологічному статусі спостерігають у разі васкулярного сифілісу мозку і сифілітичної мієлопатії у 95,2\% хворих, які проявляються у вигляді ураження черепних нервів (II - 33,7\%, III - 51,7\%, VII - 25,8\%, VIII - 10,1\%), у 71,9\% хворих пірамідного тракту (паралічі, парези), у 76,4\% хворих мозочка (статико-локомоторна і динамічна атаксія), у 40,4\% хворих спостерігають порушення функції тазових органів (нетримання сечі).

Мавров Г.І. зі співавт. у своєму дослідженні [1] роблять висновок, що сучасний НС - це захворювання 3 яскравими маніфестними проявами 3 переважанням важких форм, а не малосимптомне захворювання зі стертою клінічною картиною.

Діагноз НС встановлюють на підставі психоневрологічного обстеження, змін ліквору: плеоцитозу $>5$ кл./ $\mathrm{Mм}^{3}$, підвищення вмісту білка $>0,46$ г/л, позитивних серологічних реакцій (реакція мікропреципітації (РМП), реакції імунофлюоресценції з цільним ліквором - РІФц). Також у діагностиці НС велику роль відіграють позитивні результати серологічних реакцій 
крові - як неспецифічних (РМП), так і специфічних (РІФ, реакція пасивної гемаглютинації (РПГА), імуноферментний аналіз (IФА) [9]. Останніми роками в діагностиці НС почали застосовувати методи візуалізації комп'ютерну томографію (КТ), магнітно-резонансну томографію (МРТ) [2].

3 метою своєчасного виявлення ранніх форм НС необхідне повне обстеження хворих у терапевтичних, неврологічних, психоневрологічних, хірургічних стаціонарах, ЛОР-відділеннях за допомогою трепонемних тестів на сифіліс.

Метою даної роботи є запобігання діагностичним помилкам, пов'язаним із рідкістю виявлення сифілісу у хворих неврологічних стаціонарів у зв'язку з відсутністю специфічного серологічного дослідження крові та ліквору.

\section{Клінічний випадок}

Хворий Б., 61 рік, був направлений на консультацію в ДУ «Інститут дерматології та венерології НАМН України» з ДУ «Інститут неврології, психіатрії та наркології НАМН України», де отримував лікування у відділенні судинної патології головного мозку та реабілітації 3 діагнозом: «Енцефалопатія змішаного (дисциркуляторного, специфічного) генезу з лікворно-венозною дистензією, синдром деменції. При проведенні серологічного обстеження в стаціонарі РМП (09.07.20) позитивна.

Скарги й дані анамнезу зібрані зі слів дружини. Хворий поступив зі скаргами на порушення пам'яті на поточні події, неможливість орієнтації в часі та просторі, перепади настрою або епізоди гарного піднесеного позитивного настрою.

Анамнез захворювання: хворіє близько 3 років, коли близькі почали відмічати порушення пам'яті, почав повторювати декілька разів одне й те саме, почалися порушення орієнтації в просторі (не знав, де знаходиться, особливо під час пробудження). У січні 2019 р. на роботі оточуючі помітили у хворого порушення пам'яті, не зміг назвати число, місяць, у зв'язку з чим був госпіталізований у неврологічне відділення міської клінічної лікарні, де лікувався з 22.01.19 по 31.01.19 (діагноз: «Транзиторна глобальна амнезія на тлі закритої черепно-мозкової травми 1980 р. з постконтузійним вогнищем у ділянці лівої скроневої частки, лівого гіпокампу. Правобічна пірамідна недостатність»). Проведена МРТ головного мозку (22.01.19): виявлено структурні зміни полюсу лівої скроневої ділянки лівого гіпокампу $45 \times 15$ мм післяконтузійного характеру. Вогнища в білій речовині головного мозку дисциркуляторного характеру. Під час огляду в психіатра порушень не виявлено. Виписаний з покращенням. За даними виписки, пам'ять відновилась, порушення функцій за шкалою Ренкіна 1 бал. Призначено мему, алпазепін, нейроксон.

Через півроку знову з'явились порушення пам'яті. Було проведено МРТ-дослідження (21.08.19). Висновок: ділянки кістозно-гліозної трансформації полюсів скроневих часток, структурних змін гіпокампальних звивин, вогнищеве ураження білої речовини головного мозку, ймовірно, прояви хронічного ремітуючого запального процесу (лімбічний енцефаліт?), негативна динаміка. Дифузний атрофічний процес кори головного мозку (GCA-1; шкала загальної атрофії кори головного мозку). Остеохондроз шийного відділу хребта. Рекомендовано контроль у динаміці.
Відмічався прогредієнтний перебіг хвороби - порушення пам'яті наростали, припинив виконувати професійні обов'язки, почав блукати в раніше знайомих місцях, у зв'язку з чим у травні 2020 р. був вимушений піти з роботи. Упродовж останніх 2 тиж - значне погіршення пам'яті, орієнтації в часі та просторі, перепади настрою, у зв'язку з чим був госпіталізований у відділення судинної патології головного мозку та реабілітації ДУ «ІНПН НАМНУ» для подальшого обстеження та лікування.

Анамнез життя: дитячі інфекції, застудні захворювання, хвороба Боткіна в 1980 р. Туберкульоз і сифіліс заперечує. Спадковість не обтяжена. Травма голови (в 1980 р., не документована). Алергії немає. Зі слів хворого, в контакті з інфекційними хворими не був.

Соматичний статус: загальний стан задовільний. Шкірні покриви звичайного кольору. Над легенями везикулярне дихання. Тони серця чисті, ритмічні. АТ 105/70120/70 мм рт. ст. Пульс 64-70 уд./хв. Живіт м'який, безболісний. Печінка, селезінка не збільшені. Периферичних набряків немає. Фізіологічні відправлення в нормі.

Неврологічний статус: очні щілини і зіниці рівномірні. Конституційний екзофтальм. Фотореакції жваві. Рухи очних яблук безболісні. Недостатність акту конвергенції. Корнеальні реакції знижені. Болючість при пальпації супра- і інфраорбітальних точок. Ністагму немає. Мімічна асиметрія лицьової іннервації. Язик по середній лінії, набряклий, з відбитками зубів. М'язова сила достатня, м'язовий тонус не змінений. Сухожильні і періостальні рефлекси з кінцівок середньої жвавості, рівномірні. Патологічних знаків і порушень чутливості немає. Координаторні проби виконує задовільно. Похитування в пробі Ромберга. Біль при пальпації паравертебральних точок, особливо в поперековому відділі хребта. Вегетативна, емоційна лабільність. Порушення пам'яті. MMSE (Mini-Mental State Examination; коротка оцінка когнітивних функцій) 21 бал.

Загальні клінічні аналізи крові та сечі - без патологічних змін (03.07.20).

Електрокардіографія: гіпертрофія міокарда лівого шлуночка. Склеротичні зміні стінок аорти, стулок аортального і мітрального клапанів. Фракція викиду 65\%.

Електроенцефалографія (ЕЕГ): епілептична активність переважно у S скроневих (більше лобно-скроневих) каналах.

ЕEГ в динаміці: помірні дифузні зміни зі зниженням загального рівня біопотенціалів головного мозку з ознаками дезорганізації ритмів у лівих лобно-скроневих відведеннях. У цих самих відведеннях реєструються спалахи дельта-хвиль. Залучення стовбурових структур.

Реоенцефалографія: гіпертонічний тип. Утруднений венозний відтік.

Рентгенографія органів грудної клітки: легеневі поля без вогнищевих та інфільтративних змін. Корені структурні, не збільшені. Синуси вільні. Діафрагма чітко окреслена. Серце збільшене вліво. Аорта склерозована в ділянці дуги.

МРТ головного мозку (22.01.19): МР-картина структурних змін полюса лівої скроневої частки лівого гіпокампу $45 \times 15$ мм постконтузійного характеру. Вогнища в білій речовині головного мозку дисциркуляторного характеру. Лейкоареоз. Дифузний атрофічний процес.

МРТ головного мозку (09.07.20): ділянки кістозно-гліозних трансформацій полюсів скроневих часток і структурні зміни гіпокампальних звивин, найбільш 
Таблиця. Результати серологічного дослідження сироватки крові і ліквору хворого

\begin{tabular}{|c|c|}
\hline Сироватка крові & Ліквор \\
\hline $\begin{array}{l}\text { ІФА (сумарні антитіла) - позититивний } \\
(г 3-0,208 ; \text { опт. густина зразка - 3,304) }\end{array}$ & $\begin{array}{l}\text { ІФА (сумарні антитіла) - позитивний } \\
(г 3-0,208 ; \text { опт. густина зразка - 3,304) }\end{array}$ \\
\hline РПГА позитивна; 4+ & РПГА позитивна; 4+ \\
\hline 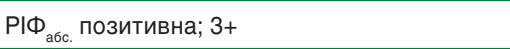 & PІФ абс. позитивна; 3/4+ \\
\hline РМП позитивна 4+; 1/8++ & РМП- негативна \\
\hline $\begin{array}{l}\text { ІБТ - виявлені } \\
\text { Тр } 15 \text { (гз - 0,144, опт. густина зразка 3,237) } \\
\text { Tр } 17 \text { (гз - 0,135, опт. густина зразка 2,911) } \\
\text { Тр } 41 \text { (гз - 0,128, опт. густина зразка 3,093) } \\
\text { Tр } 47 \text { (гз - 0,125, опт. густина зразка 3,112) }\end{array}$ & $\begin{array}{l}\text { ІБТ - виявлені } \\
\text { Тр } 15 \text { (гз - 0,144, опт. густина зразка 3,526) } \\
\text { Tр } 17 \text { (гз - 0,135, опт. густина зразка 2,912) } \\
\text { Tр } 41 \text { (гз - 0,128, опт. густина зразка 2,170) } \\
\text { Tр } 47 \text { (гз - 0,125, опт. густина зразка } 3,257)\end{array}$ \\
\hline
\end{tabular}

вірогідно, внаслідок хронічного запального процесу. Множинні судинні вогнища в головному мозку як прояви дисциркуляторних змін. Помірна зовнішня гідроцефалія. Гіпотрофія кори головного мозку. Порівняно з даними МРТ від 21.08.19 - без негативної динаміки.

Консультація психолога: мають місце нейрокогнітивні порушення вираженого ступеня. Синдром деменції (показник за шкалою MMSE - 21 бал). Нейропсихологічні ознаки домінуючої дисфункції лобно-скроневих структур головного мозку.

Консультація психіатра: домінують когнітивні порушення лобно-скроневої локалізації (значне зниження пам'яті, мореоподібний настрій). Висновок: деменція (F 03).

Консультація терапевта: НЦД за гіперонічним типом.

Консультація в ДУ «ІДВ НАМНУ»: нейросифіліс? Для підтвердження діагнозу необхідно провести серологічне дослідження ліквору та сироватки крові.

Аналіз спинномозкової рідини (20.07.20): цитоз $5 \times 10^{6} /$ л, білок 0,21 г/л, цукор 3,4 ммоль/л, реакція Нонне-Апельта - опалесціююча.

Серологічне дослідження сироватки крові та ліквору було проведено в ДУ «ІДВ НАМНУ». Дані обстеження наведено в таблиці.

Дружина Б., 60 років. Сифіліс в анамнезі заперечує. У ДУ «ІДВ НАМНУ» було проведено серологічне обстеження.

Сироватка крові: ІФА (сумарні антитіла) - позитивний (гз - 0,208; оптична густина зразка - 2,135; РПГА позитивна (3+); РІФ абс. - слабо-позитивна $(2+)$; РМП негативна; ІБТ - виявлені Тр 15 (гз - 0,144, оптична

\section{Література}

1. Два случая нейросифилиса / Г.И. Мавров, Г.А. Дудаева, В.А. Савоськина [и др.]. Дерматология и венерология. 2002. № 3 (17). С. 63-64.

2. Клінічний випадок пізнього сифілісу на фоні наслідків важкої черепно-мозкової травми / Г.М. Бондаренко, І.М. Нікітенко, О.А. Безрученко [та ін.]. Дерматологія та венерологія. 2020. № 2(88). С. 38-41.

3. Красносельских Т.В. Нейросифилис. Спб.: Сотис, 2001. 340 с

4. Мавров И.И. Половые болезни: руководство для врачей, интернов и студентов. Харьков: Факт, 2002. 789 с.

5. Маргулис М.С. Ранний нейросифилис. М.: Медгиз, 1949. 248 с.

6. Практические аспекты серологической диагностики сифилиса на современном этапе / Я.Ф. Кутасевич, В.В. Кутовая, О.Н. Белоконь [и др.]. Дерматология и венерология. 2020. № 1 (87). С. 39-43.

7. Проблема диагностики и регистрации нейросифилиса / Г.Д. Селисский, Ф.В. Хубиева, И.В. Зуева [и др.]. Вестн. последипломного медицинского образования. 2003. № 3-4.

8. Ретюнский К.Ю., Сурганова В.И., Колчанов А.Г. Проблема диагностики и терапии боль-
С1-32. ных поздним нейросифилисом в условиях психиатрического стационара. Современная терапия психических расстройств. 2009. № 2. С. 7-9.

9. Родиков М.В., Шпрах В.В. Нейросифилис. Журн. неврологии и психиатрии. 2009. № 2. C. $78-81$.

10. Современные проблемы ведения больных нейросифилисом / О.К. Лосева, А.В. Аншуков, С.А. Бахтин [и др.]. Клиническая дерматология и венерология. 2007. № 4. C. $51-53$.

11. Сифилис нервной системы у пациентов, лечившихся по поводу сифилиса в прошлом / О.В. Залевская, Л.Б. Важбин, О.К. Лосева [и др.]. Клиническая дерматология и венерология. 2010. № 3. С. 76-81.

12. Cervical syphilitic spondylodiscitis associated with neurosyphilis / J. Payet, R. Sero

Hanss

13. Marra C.M. Neurosyphilis. Curr. Neurol. Neurosci. Rep. 2004. Vol. 4, N6. P. 435-440. густина зразка - 3,346), Тр 17(гз - 0,135, оптична густина зразка 0,812$),$ Тр 41 (гз - 0,128, оптична густина зразка - 0,230) - слабо-позитивний. Не виявлені - Тр 47 (гз - 0,125, оптична густина зразка - 0,065).

Під час огляду активні прояви сифілісу відсутні. Установлено діагноз: сифіліс латентний пізній. Рекомендована терапія згідно з наказом МОЗ України.

На підставі отриманих результатів серологічного обстеження, анамнезу захворювання, даних додаткового та серологічного обстеження дружини встановлено діагноз: «Нейросифіліс. Енцефалопатія змішаного (дисциркуляторного, специфічного) генезу з лікворо-венозною дистензією. Синдром деменції». Рекомендовано два курси специфічної терапії у венерологічному відділенні ДУ «ДВ НАМНУ».

Після проведеної терапії отримано позитивний клінічний ефект у вигляді помірного регресу когнітивних розладів, а також позитивний лабораторний ефект у вигляді зниження титрів трепонемних тестів сироватки крові. Для оцінки ефективності проведеної терапії хворому рекомендовано повторне лікворологічне обстеження через 6 міс.

\section{Висновки}

Цей клінічний випадок демонструє необхідність лікворологічного обстеження всіх пацієнтів неврологічного стаціонару, що мають позитивний результат нетрепонемних і трепонемних тестів із сироваткою крові. Тільки дослідження ліквору в комплексному серологічному обстеженні дає змогу діагностувати НС.

\section{References}

1. Dva sluchaia neirosyfylysa [Two cases of neurosyphilis]. Dermatolohyia ta venerolohyia. 2002;3(17):63-64.

2. Bondarenko HM, Nikitenko IM, Bezruchenko OA, et al. Klinichnyi vypadok piznoho syfilisu na foni naslidkiv vazhkoi cherepno-mozkovoi travmy [A clinical case of late syphilis on the background of the consequences of severe traumatic brain injury]. Dermatolohila ta venerolo-
hiia. 2020:2(88):38-41. hiii. 2020;2(88):38-4

3. Krasnoselskykh TV. Neirosyfylys (Neurosyphilis). SPb.: Sotys, 2001. 340 p.

4. Mavrov YY. Polovye bolezny: rukovodstvo dlia vrachei, ynternov y studentov [Sexually transmitted diseases: a guide for doctors, interns and students]. Kharkov: Fakt, 2002. $789 \mathrm{p}$

5. Marhulys MS. Rannyi neirosyfylys [Early neurosyphilis]. M.: Medhyz, 1949. 248 p.
6. Kutasevych YaF, Kutovaya VV, Belokon' ON, et al. Praktycheskye aspekty serolohycheskoi 6. Kutasevych YaF, Kutovaya $\mathrm{W}$, Belokon' ON, et al. Praktycheskye aspekty serolohychesko
dyahnostyky syfylysa na sovremennom etape [Practical aspects of serological diagnosis of syphdyahnostyky syfylysa na sovremennom etape [Practical aspects of serological
ilis at the present stage]. Dermatolohyia ta venerolohyia. 2020;(87):39-43.

5 at the present stage]. Dermatolohyia ta venerolohyia. 2020;(87):39-43.
7. Selysskyi HD, Khubyeva FV, Zueva YV, et al. Problema dyahnostyky y rehystratsyy neirosy7. Selysskyi HD, Khubyeva FV, Zueva $\mathrm{Y}$, et al. Problema dyahnostyky y rehystratsyy neirosy-
ylysa [The problem of diagnosing and registering neurosyphilis]. Vestn. posledyplomnoho mefylysa [The problem of diagnosing and registering
dytsynskoho obrazovanyia. 2003;3-4:31-32.

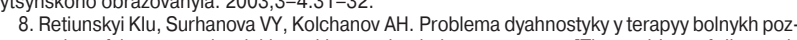
dnym neirosyfylysom v uslovyiakh psykhyatrycheskoho statsyonara [The problem of diagnosis and therapy of patients with late neurosyphilis in a psychiatric hospital]. Sovremennaia terapyia and therapy of patients with late neurosyphin
psykhycheskykh rasstroistv. 2009:2:7-9.

9. Rodykov MV, Shprakh W. Neirosyfylys [Neurosyphilis]. Zhurn. nevrolohyy y psykhyatryy. 2009:2:78-81.

10. Loseva OK, Anshukov AV, Bakhtyn SA, et al. Sovremennye problemy vedenyia bolnykh neirosyfylysom [Modern problems of management of patients with neurosyphilis]. Klynycheskaia dermatolohyia y venerolohyia. 2007:4:51-53.

11. Zalevskaia OV, Vazhbyn LB, Loseva OK, et al. Syfylys nervnoi systemy u patsyentov, lechyvshykhsia po povodu syfylysa v proshlom [Syphilis of the nervous system in patients treated chyvshykhsia po povodu syfylysa v proshlom [Syphilis of the nervous system in patients
for syphilis in the past]. Klynycheskaia dermatolohyia y venerolohyia. 2010;3:76-81. for syphilis in the past]. Klynycheskaia dermatolohyla y venerolohyla. 2010;3:76-81.
rosyphilis. Rheumatology. 2011;50(9): 1723-1725.

13. Marra CM. Neurosyphilis. Curr. Neurol. Neurosci. Rep. 2004;4(6):435-440. 


\section{СЛУЧАЙ ПРОГРЕССИВНОЙ ДЕМЕНЦИИ НА ФОНЕ ПОЗДНЕГО НЕЙРОСИФИЛИСА}

Г.М. Бондаренко, И.Н. Никитенко, А.А. Безрученко, В.В. Кутовая, Т.В. Губенко

ГУ «Институт дерматологии и венерологии НАМН Украины»

Резюме

Цель. Предотвращение диагностических ошибок, связанных с редкостью выявления сифилиса у больных неврологических стационаров.

Результаты. Приведен клинический случай из практики врачей-дерматовенерологов.

Выводы. Для своевременного выявления нейросифилиса необходимо проводить ликворологическое обследование всех пациентов неврологического стационара, имеющих положительный результат нетрепонемных и трепонемных тестов в сыворотке крови.

Ключевые слова: нейросифилис, T. pallidum, деменция, диагностика нейросифилиса.

\section{A CASE OF PROGRESSIVE DEMENTIA ON THE BACKGROUND OF LATE NEUROSYPHILIS}

G.M. Bondarenko, I.N. Nikitenko, A.A. Bezruchenko, V.V. Kutova, T.V. Gubenko $S E$ «Institute of Dermatology and Venereology of NAMS of Ukraine»

Abstract

The objective. Prevention of diagnostic errors associated with the rare detection of syphilis in patients in neurological hospitals. Results. A clinical case from the practice of dermatovenereologists is given.

Conclusions. For timely detection of neurosyphilis it is necessary to conduct a cerebrospinal fluid examination of all patients in the neurological hospital who have a positive result of non-treponemal and treponemal tests in the serum.

Key words: neurosyphilis, T.pallidum, dementia, diagnosis of neurosyphilis.

Відомості про авторів:

Бондаренко Гліб Михайлович - д-р мед. наук, професор, завідувач відділу інфекцій, що передаються статевим шляхом, ду «Інститут дерматології та венерології НАМН України»; e-mail: bondarenko.kharkov@gmail.com

ORCID ID: https://orcid.org/0000-0002-0799-797X

Нікітенко Інна Миколаївна - канд. мед. наук, ст. наук. співроб. відділу інфекцій, що передаються статевим шляхом, Ду «Інститут дерматології та венерології НАМН України»; e-mail: nikitenko.inna.n@gmail.com

ORCID ID: https://orcid.org/0000-0001-8315-7625

Безрученко Олексій Анатолійович - канд. мед. наук, ст. наук. співроб., лікар відділення венерології ду «/нститут дерматології та венерології НАМН України»; e-mail: alekseybezruchenko71@gmail.com

ORCID ID: https://orcid.org/0000-0001-6436-4354

Кутова Валентина Василівна - канд. мед. наук, ст. наук. співроб., завідувачка лабораторії серології ду «Інститут дерматології та венерології НАМН України»; е-mail: serolab_idv@i.ua

ORCID ID: https://orcid.org/0000-0002-0799-797X

Губенко Тетяна Володимирівна - канд. мед. наук, мол. наук. співроб. відділу інфекцій, що передаються статевим шляхом, ДУ «Інститут дерматології та венерології НАМН України»; e-mail: tanyagubenko63@gmail.com

ORCID ID: https://orcid.org/0000-0001-9442-0409 